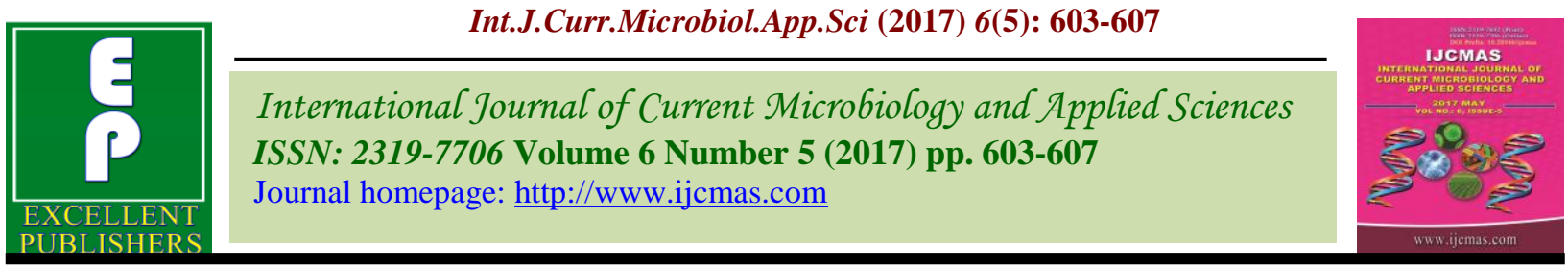

Case Study

https://doi.org/10.20546/ijcmas.2017.605.069

\title{
Immune Mediated Haemolytic Anaemia Secondary to Sheathed Microfilaria - A Case Report
}

\author{
M. Ashwini* and Usha Narayana Pillai \\ Department of Veterinary Clinical Medicine, College of Veterinary and Animal Sciences, \\ Mannuthy, India \\ *Corresponding author
}

\begin{tabular}{|c|c|}
\hline & A B S T R A C T \\
\hline $\begin{array}{l}\text { Sheathed } \\
\text { microfilaria; } \\
\text { Brugia spp; } \\
\text { Immune mediated } \\
\text { haemolyticanaemia } \\
\text { (IMHA); } \\
\text { Coombs' test. }\end{array}$ & \multirow{3}{*}{$\begin{array}{l}\text { A one year old female Labrador dog was presented to University Veterinary Hospital } \\
\text { Kokkalai, with a history of anorexia, weakness, blood in urine and faeces. On physical } \\
\text { examination mucous membranes were pale icteric, fever }\left(105.3^{0} \mathrm{~F} \text { ), tachypnoea was }\right. \\
\text { noticed. Abdominal palpation revealed splenomegaly which was confirmed by } \\
\text { ultrasonography. Haemotological examination revealed leucocytosis, severe macrocytic } \\
\text { hypochromic anaemia (VPRC-9.4\%) and thrombocytopenia. Wet film was positive for } \\
\text { microfilaria and confirmed as brugiaspp on Giemsa staining of thick blood smear. } \\
\text { Leptospirosis was ruled out by MAT. Biochemical studies showed hyperglobulinema, } \\
\text { elevated ALT and indirect bilirubin. The blood was positive for saline agglutination test } \\
\text { and further antiglobulin test was carried out at } 37^{\circ} \mathrm{C} \text { using VMRD polyvalent Coombs' } \\
\text { reagent which was positive at } 1: 32 \text { dilution. Treatment was initiated with a dexamethasone } \\
\text { @ } 0.5 \mathrm{mg} / \mathrm{kg} \text { IV for } 7 \text { days, then tapered to } 0.25 \mathrm{mg} / \mathrm{kg} \text { for } 7 \text { days and } 0.125 \mathrm{mg} / \mathrm{kg} \text { for } \\
\text { next } 7 \text { days PO. The pet was transfused with } 250 \text { ml of whole blood on the day of } \\
\text { admission and supportive therapy with amoxicillin-clavulanic acid } 600 \mathrm{mg} \text { IV (14 days), } \\
\text { levamisole @ } 10 \mathrm{mg} / \mathrm{kg} \text { for } 10 \text { days, pantoprazole and haematinics were given. The pet } \\
\text { made an uneventful recovery. }\end{array}$} \\
\hline Article Info & \\
\hline $\begin{array}{l}\text { Accepted: } \\
\text { 04 April } 2017 \\
\text { Available Online: } \\
10 \text { May } 2017\end{array}$ & \\
\hline
\end{tabular}

\section{Introduction}

Immune-mediated hemolytic anemia (IMHA) is considered as one of the most common immune-haemotological disorders in dogs in which antibodies are produced against the body's erythrocytes (Klag et al., 1993). The condition can occurs as primary/ idiopathic and secondary forms. Primary IMHA is not associated with any known existing cause, while secondary IMHA is usually associated with various etiologies such as infectious diseases, drugs, or neoplasia (Pedersen, 1999). Various blood parasites such as Anaplasmaspp, Ancylostomacaninum,
Babesiacanis,

Babesiagibsoni, Dirofilariaimmitis (Heart worm), Ehrlichia spp and many diseases such as histoplasmosis, leishmaniasis, leptospirosis, mycoplasmosis had been implicated as the cause for secondary IMHA in dogs (Archer and Mackin, 2013). The current paper describes a case of IMHA, associated with sheathed microfilariae.

\section{Case Report and Method}

One year old Labrador was presented with the signs of anorexia, weakness, blood in urine 
and faeces. On physical examination pale icteric mucous membrane (Fig 1), fever $\left(105.3^{0} \mathrm{~F}\right)$, tachypnoea was noticed. Splenomegaly was noted on abdominal palpation. Routine haemotology and serum biochemical analysis is presented in table 1 and 2 respectively. On the day of presentation the dog was severely anaemic (macrocytic hypochromic) with high leucocyte count and thrombocytopenia. Differential leucocyte countrevealed lymphocytosis, monocytosis and granulocytosis. Serum biochemistry analysis revealed hyperglobulinemia, hyperbilirubinemia, high alanine amino transferase and alkaline phosphatase levels.

Routine clinical examinations such as wet film, blood smear was stained with Giemsa' examination was done. Serum was checked for MAT to rule out leptospirosis. Severe acuteanaemia prompted for performing saline agglutination test which was positive (Fig 2). Later Coombs' test was performed at $37^{\circ} \mathrm{C}$ using VMRD canine polyvalent Coombs' reagent (Goat origin anti canine $\operatorname{IgG}, \operatorname{IgM}$ and $\mathrm{C}_{3}$ ) to confirm IMHA. The test was positive at 1:32 titer (Fig 3).Wet film was positive for moving haemoparasite suggestive of microfilariae. On examination of Giemsa stained blood smear the microfilaria was confirmed as sheathed microfilaria (Fig 4) and no other haemoparasite could be detected. But spherocytosis (Fig 4) was evident on the blood smear. Immune mediated haemolyticanaemia secondary to sheathed microfilariae was diagnosed on the second day.

On the day of presentation the animal was transfused with $250 \mathrm{ml}$ of whole blood from a healthy donar dog and amoxicillin-clavulanic acid $600 \mathrm{mg}$ IV. The treatment was initiated for IMHA and microfilariosis with dexamethasone @ $0.5 \mathrm{mg} / \mathrm{kg}$ IV for 7 days andlevamisole @ 10mg/kg PO for 10 days respectively. Dexamethasone was later tapered $0.25 \mathrm{mg} / \mathrm{kg}$ for 7 days, subsequently to $0.125 \mathrm{mg} / \mathrm{kg}$ for next 7 days PO. Antibiotics were continued for 14 days.

\section{Results and Discussion}

The dog made an uneventful recovery after the treatment. Wet film examination and saline agglutination were repeated on day 14 and 21 and was found to be negative. The haemato-biochemical changes after the initiation of treatment is represented in table 1 and 2. There was raise in erythrocyte count, haemoglobin level and VPRC. Platelet count, leucocyte count returned to normal by day 14. There was marked increase in ALP value, which might be due to immunosuppressive therapy.

Immune mediated hameolyticanaemia is characterized by moderate to severe anaemia, autoagglutination, spherocytosis, positive Coombs' test (Klag et al., 1993). In the present study the dog had characteristic signs of IMHA. The Coombs' test or antiglobulin test which demonstrates the presence of antierythrocyte antibodies was also performed to confirm the diagnosis, which was found to be positive at 1:32 titer. Many studies have confirmed various haemoparasites to act as a trigger for IMHA (Archer and Mackin, 2013). Recent vaccination and drug therapy are implicated in secondary IMHA (Duval and Giger, 1996; Garratty, 2010).

But the dog here was not under any drug therapy and was not vaccinated recently. In this case sheathed microfilaria was considered to be the trigger because no other underlying causes could be identified and complete recovery was noticed after immunosuppressive and levamisole treatment. Kerala is endemic for microfilariosis, as suggested by Chirayath, (2013) and occurrence of microfilariosis in dogs was 8.12 per cent. 
Table.1 Haemological changes recorded in the present case study

\begin{tabular}{|c|c|c|c|c|c|}
\hline $\begin{array}{c}\text { Haemotological } \\
\text { Parameters }\end{array}$ & $\begin{array}{c}\text { Reference } \\
\text { range }\end{array}$ & Day 0 & Day 5 & Day 14 & Day 21 \\
\hline RBC $\left(10^{6} / \mu 1\right)$ & $5.50-8.50$ & 0.89 & 1.65 & 3.56 & 3.04 \\
\hline HGB $(\mathrm{g} / \mathrm{dl})$ & $12.0-18.0$ & 2.3 & 4.7 & 7.0 & 9.9 \\
\hline VPRC $(\%)$ & $37.0-55.0$ & 9.4 & 16.8 & 26.4 & 24.1 \\
\hline $\mathrm{MCV}(\mathrm{fL})$ & $60.0-77.0$ & 105.6 & 101.8 & 74.2 & 79.3 \\
\hline $\mathrm{MCH}(\mathrm{pg})$ & $19.0-25.0$ & 25.8 & 28.5 & 19.7 & 32.6 \\
\hline $\mathrm{MCHC}(\mathrm{g} / \mathrm{dL})$ & $32.0-36.0$ & 24.5 & 28 & 26.5 & 41.1 \\
\hline $\mathrm{RDW}(\%)$ & $11.0-14.0$ & 15 & 23.4 & 19.3 & 13.2 \\
\hline PLT $\left(\times 10^{3} / \mu 1\right)$ & $160-525$ & 98 & 139 & 368 & 164 \\
\hline WBC $\left(10^{3} / \mu 1\right)$ & $6.0-17.0$ & 83.7 & 37.6 & 16.5 & 8.6 \\
\hline $\mathrm{LYM}\left(10^{3} / \mu 1\right)$ & $0.7-5.1$ & 34.4 & 17.2 & 4.5 & 1.5 \\
\hline MON $\left(10^{3} / \mu 1\right)$ & $0.2-1.7$ & 7.6 & 3.5 & 2.4 & 0.4 \\
\hline GRAN $\left(10^{3} / \mu 1\right)$ & $4.4-12.6$ & 41.7 & 16.9 & 9.6 & 6.7 \\
\hline
\end{tabular}

Table. 2 Biochemical changes recorded in the present case study

\begin{tabular}{|c|c|c|c|c|}
\hline Serum biochemistry & $\begin{array}{c}\text { Reference } \\
\text { range }\end{array}$ & Day 0 & Day 14 & Day 21 \\
\hline Total protein (g/dl) & $5.4-7.1$ & 8.275 & 4.542 & 4.076 \\
\hline Albumin (g/dl) & $2.6-3.3$ & 2.914 & 2.694 & 2.756 \\
\hline Globulin (g/dl) & $2.7-4.4$ & 5.361 & 1.848 & 1.32 \\
\hline A:G & $0.9-0.75$ & 0.543 & 1.457 & 2.087 \\
\hline Total bilirubin (mg/dl) & $0.10-0.5$ & 12.78 & 2.069 & 0.037 \\
\hline Direct Bilirubin (mg/dl) & $0.06-0.12$ & 4.337 & 1.319 & 0.733 \\
\hline $\begin{array}{c}\text { Indirect Bilirubin } \\
\text { (mg/dl) }\end{array}$ & $0.01-0.49$ & 8.443 & 0.75 & 0.696 \\
\hline ALT (U/L) & $21-102$ & 326.5 & 36.02 & 5.196 \\
\hline ALP (U/L) & $23-66$ & 83.73 & 764.8 & 845.9 \\
\hline BUN (mg/dl) & $10-28$ & 14.16 & 19.663 & 28.037 \\
\hline Creatinine (mg/dl) & $0.5-1.5$ & 0.424 & 1.126 & 0.857 \\
\hline
\end{tabular}

Fig.1 Pale icteric mucous membrane and haemoglobinuria on the day of presentation
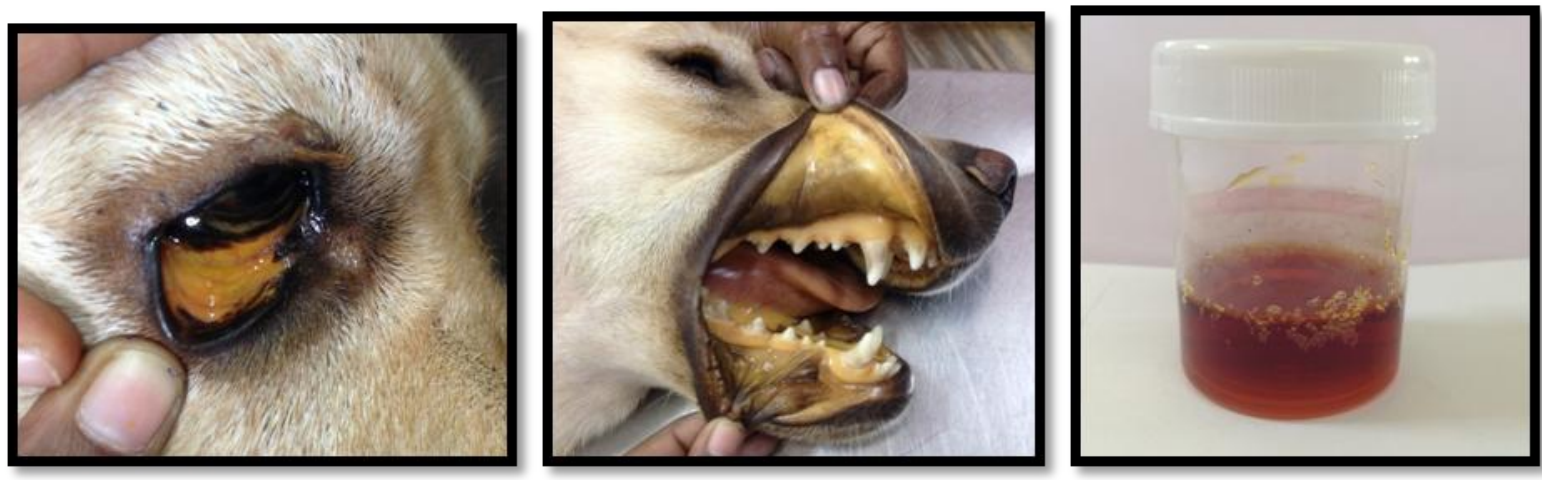
Fig.2 Postive saline agglutination test
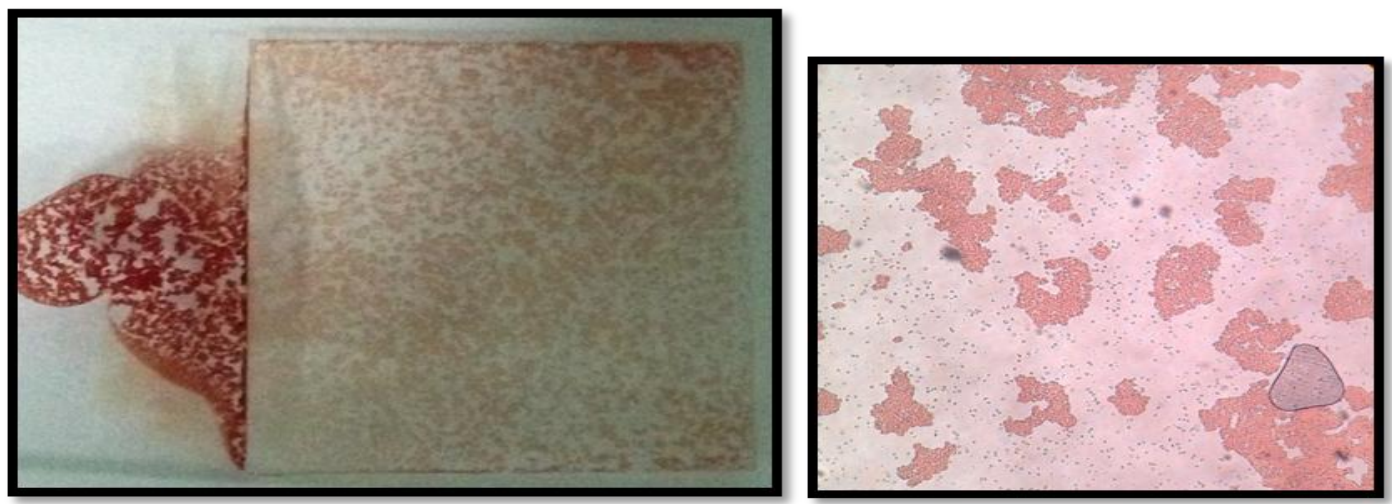

Fig.3 Microtiter method of Coombs' test positive at 1:32 titer

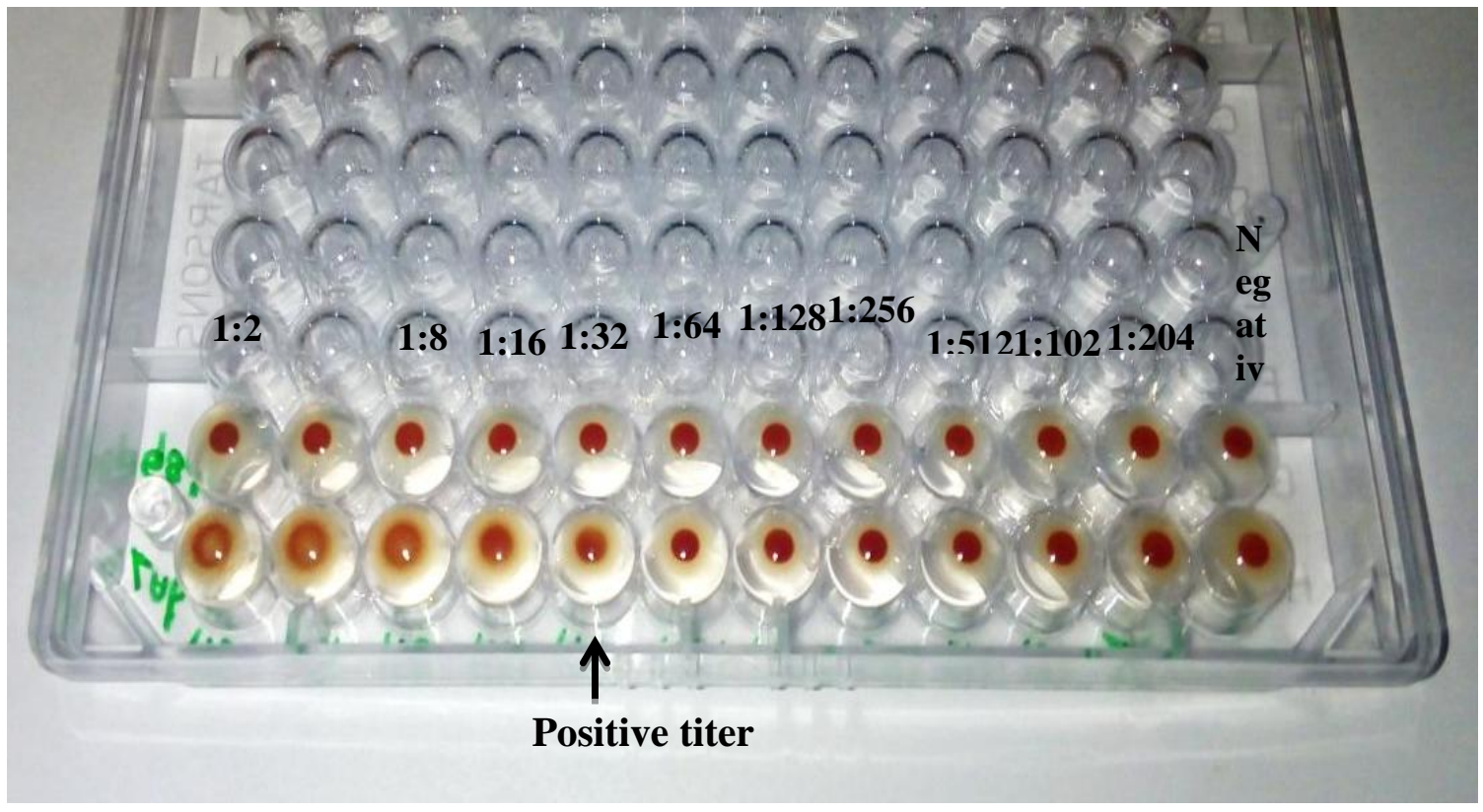

Fig.4 Blood smear examination: Sheathed microfilaria and Spherocytosis
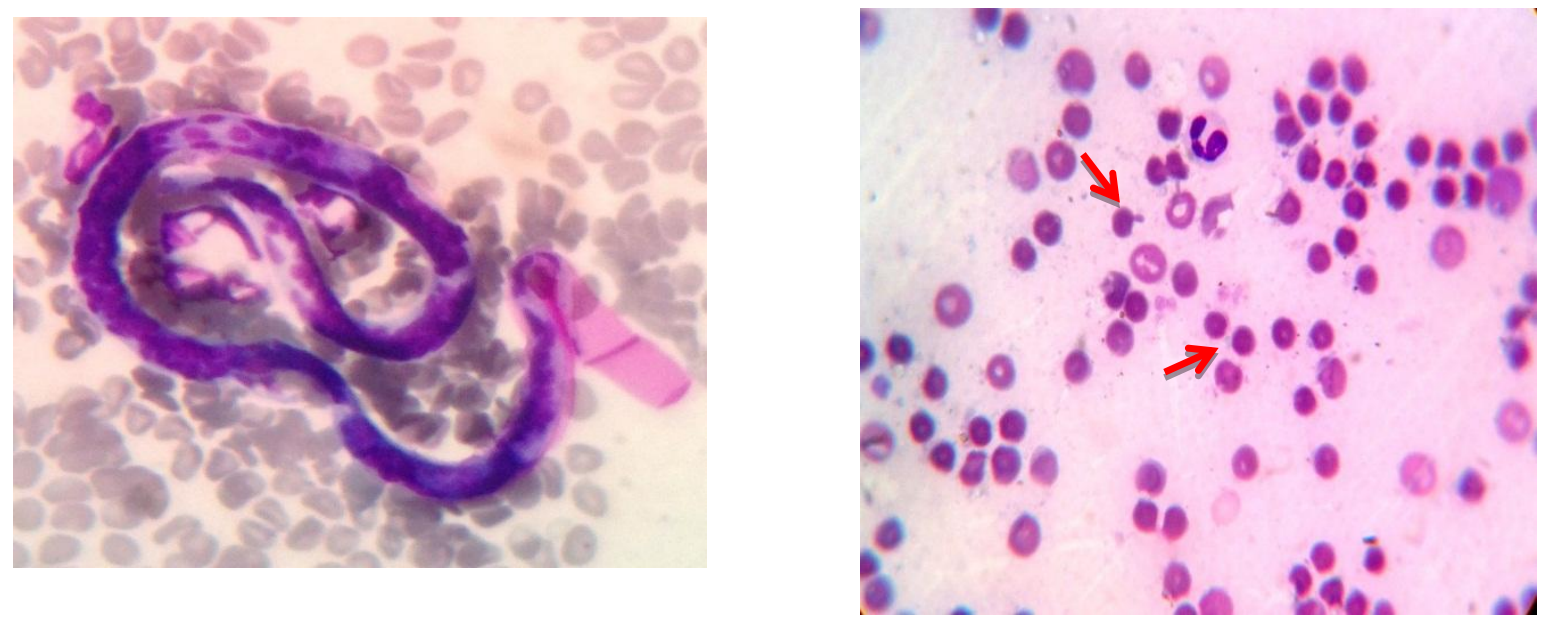
Anaemia in microfilariosis might be due to motility of the organism leading to mechanical destruction of RBC (Chirayath, 2013). Also auto agglutination of erythrocytes was reported earlier by Hashem and Badaway (2008).

Direct and indirect Coombs' test was found to be positive in a human infected with Wuchereriabancrofti (Srinivas, 2003). Dirofilariaimmitis is known to act as a trigger for IMHA (Archer and Mackin, 2013). No species identification was carried out in the present study.

In conclusion, currently the role of antierythrocyte antibody in microfilariosis is unknown. Based on the present case the role of microfilaria in causing IMHA cannot be excluded. Further detailed study regarding the presence of antierythrocyte antibody using flow cytometry in microfilaria infected dogs should be carried out.

\section{Acknowledgements}

The author duly acknowledges the Dean, College of Veterinary and Animal Science, Mannuthy for providing facilities for conduct of the research. This study is part of M.V.Sc thesis submitted by the first author to Kerala Veterinary and Animal Sciences University, Pookode.

\section{References}

Archer, T. and Mackin, A. 2013. Diagnosis of immune-mediated hemolytic anemia. Today's Vet. Practice, 3(4): 32-36.

Chirayath, D. 2013. Molecular characterization and therapeutic management of microfilariae in dogs. Ph.D thesis, Kerala Veterinary and Animal Sciences University, Pookode, $173 p$.

Duval, D. and Giger, U. 1996. Vaccineassociated immune-mediated hemolytic anemia in the dog. J. Vet. Int. Med., 10(5): 290-295.

Garratty, G. 2010. Immune hemolytic anemia associated with drug therapy. Blood Rev., 24: 143-150.

Hashem, M., and Badawy, A. 2008. Hematological and biochemical studies on filariasis of dogs. Int. J. Vet. Med., 4(2): 1-7.

Klag, A.R., Giger, U. and Shofer, F.S. 1993. Idiopathic immune-mediated hemolytic anemia in dogs: 42 cases (1986-1990). J. Am. Vet. Med. Assoc., 202: 783-788.

Pedersen, N.C. 1999. A review of immunologic diseases of the dog. Vet. Immunol. Immunopathol., 69: 251-342.

Srinivas, U.M. 2003. Severe bone marrow alpasia and Coombs'-positive autoimmune hemolytic anemia in microfilariasis - coincidental or causal? Images in Hematol., 157: 1.

\section{How to cite this article:}

Ashwini, M., and Usha Narayana Pillai. 2017. Immune Mediated Haemolytic Anaemia Secondary to Sheathed Microfilaria - A Case Report. Int.J.Curr.Microbiol.App.Sci. 6(5): 603607. doi: https://doi.org/10.20546/ijcmas.2017.605.069 